\title{
Teachers' Management Planning and Implementing for the Success of EFL Learning
}

\author{
Absharini Kardena \\ absharinikardena@yahoo.co.id \\ IAIN Bukittinggi \\ West Sumatera, Indonesia
}

\begin{abstract}
Group work as one of teaching techniques on the framework of communicative approach is believed to be an effective model for building students' communicative competence. The process of applying this technique needs high skills of management of the English teacher. The English teacher has autonomy to plan and implement the group work in order to achieve an objective of EFL learning. Because of that, the English teacher has a responsibility to make any decisions and actions for assuring the success of EFL learning. The teachers' management in planning and implementing group work influenced the success of this teaching technique. This article, which is derived and further developed based on research conducted in 2013, analyzes and discusses the way the teachers plan and implement group work for the success of EFL learning. This research was done at MAN Kota Solok as one of Islamic senior high school in Solok city. The research was conducted in terms of qualitative research by involving 3 English teachers at MAN kota Solok. The research found that the teachers still need some guidance and improvements in planning and implementing group work for students at MAN Kota Solok.
\end{abstract}

Keywords: management, planning, implementing, group, work

\section{Introduction}

During the development of teaching English as a second/ foreign language, many issues related to effective teaching techniques have emerged. The main focus of the development is to develop students' communicative competence. One of the ways is activating students' participation in the classroom. In fact, involving students to participate in the classroom is not an easy task if the students have been familiar with teacher-centered instruction. In this case, group work is promoted as an effective teaching technique to encourage students' participation. Since the group work demands the students to work together in a group, they have to discuss and participate for accomplishing the task. As stated by McDonough (1993), group work is one of the techniques that require a cooperative environment which can allow an establishment of the cohesive and collaborative working atmosphere.

In the process of implementing group work, some practitioners assume that a teacher is not directly involved in conducting the group work. This assumption is based on an argument that the students are the ones who work actively on the groups, as a widely known as learner-centered instruction. In the other side, many experts state that the teacher cannot be immediately separated from the process of group work. In fact, the teacher is the one who has a control in the classroom. Although the learning principle applied in the classroom is learner-centered instruction, the teacher has a part to take a control and manage the group work in such a way. 
In accordance with teacher's roles in controlling group work, research in group work is essentially needed. Related to this point, this article is developed based on a research done in 2013 at MAN Kota Solok. Based on the research, this article elaborates how the teachers manage the group work in

\section{Literature Review}

Many practitioners have developed some definitions of group work from different points of view. Evertson (1984) proposes a definition about group work. He states that group work is an activity in which two or more students work together on a task that requires their cooperation. Brown (1994: ) argues that group work is "a generic term covering a multiplicity of techniques in which two or more students are assigned a task that involves collaboration and selfinitial language." Brown's opinion is established based on the techniques that might be used in group work and also the size for each group. Previously, Evertson (1984) also proposes the similar idea of what group work is. Both the experts offer a point that group work must consist of two or more members because it is a kind of peer learning.

Other idea is given by Smith (2008) who determines group work in a more detail definition. It is explained in four detail definitions that; (i)group work are two or more individual who are connected to one another by social relationship; (ii) group work is a fundamental part of human experience that may develop more complex and larger activities and provide setting where people can find help and support; (iii) group work are social relationship that involved inter independence among the members of the group; and (iv) group work are determined as an activity that involved some members in which the groups itself might be grouped directly by the members or it is grouped emergently. In other word, terms of applying learner-centered instruction in curriculum 2013. This article is aimed to explain the way the teachers plan and implement the group work. It can explain teachers' point of view about their roles during the implementation of group work.

Smith (2008) defines group work based on the size of the members for each group, functions of group work, advantages of group work, and the process of grouping the members.

On the other hand, McDonough (1993) explains group work on the range of education field, especially on the implementation of it in the classroom. He defines group work as an organization that is handled by teacher and it can be activated in most classrooms that have a comparable range of functions, have a more complex structure which may involve different roles for each member of groups as well as a certain amount of physical re-organization of the classroom.

From all of those statements above, it can be academically stated that group work can be defined based on the size of the group member, the functions and the advantages, the process during the activity and the process of grouping the member for the groups. In other words, group work can be explained as an activity that may involve two or more students who are assigned a task in some techniques and require peer learning and peer support.It also offers help and support for them. In addition, the members of a group may be formed by students themselvesor grouped by teacher and it may also require different roles for each member of the groups.

Moreover, the teacher still has responsibility of running the group work in the classroom. In other word, the teacher has their own role in conducting group work for 
students. One of the teacher's roles in managing the group work is planning the group work. There are several points that should be done by the teacher. The first one is selecting the appropriate activity for students. Brown (1994) classifies the appropriate activity by considering type of group work; pair works and smaller group work. Brown (1994) states that there are some activities that are appropriate for pair works, such as practicing dialogue with partner, simple question and answer exercises, performing meaningful substitution drills, quick brainstorming, checking written work, etc. On the other hand, the activities that can be applied for smaller group work are games, role play, simulations, drama, project, interview, brainstorming, information gap, jigsaw, problem solving and decision making, opinion exchange, etc. Brown's opinion is strengthened by Nation (1989) who states that the activity chosen for group work should be established and appropriated in line with the goal and aims of teaching and learning processes.

The second step is deciding the goals of the activity. The goals of group work should be clear in this stage so that the students have a target that should be achieved in doing this activity (Nation, 1989). It is supported by Brooks (2010) who states that in order to obtain a higher level of thinking, it is important to the groups to focus to specific goals. In a more detail explanation, Deckert (2004) explains that the teacher should explain the clear goals and expectation of the activity. It includes the description of any tasks that require group work as well as any information. Because of that, the teacher is recommended to explain the goals; what students should achieve at the end of the lesson.
Then, the next point is determining the size of the groups. Harmin (1994) explains that in determining the size of the groups, there are some important aspects that should be noticed by the teacher. The first one is smaller group work are better rather than the bigger one because it can maximize students' participation. Moreover, it is also less noisy and promotes good eye contact that helps the students to produce respectful relationship. The second one is avoiding trios because two of the three students are often more compatible with one another. The last one is group of four tends to lead to passive participation if the group members consist of different capability among them. However, it is suggested to be applied if the task calls much creativity or many different perspectives that can maximize students' involvement since each member of the groups may offer the variety of ideas and perspective.

Besides determining the group size, there is also another important aspect; determining the members of the group. Cohen (1994) states an important aspect in determining the members of the group. He suggests using self-selection. Related to the criteria used to form the group, Hayden (2010) explains that in grouping the students, the teachers should pay attention to the types of the group. She offers two kinds of groups; heterogeneous and homogeneous. In heterogeneous group, the students are combined based on a wide range of abilities. It is usually used in order to train students how to work together by people with different strengths to complete a task. In homogeneous group, the students who are grouped together have similar interest and abilities. The main aim of applying this kind of group is the talented students can speed ahead and learn at their level ability. 
After planning the group work, the next step is the most important point in managing the group work; managing the implementation of group work. The teacher has a great contribution in monitoring, facilitating, and organizing the group work. Although the students are the center of group work activity, the teacher still has a part in controlling how the students do the activity. Because of that, the teacher should know how to monitor, facilitate, and organize the group work.

One of the teacher's role in this case is giving explicit detailed instructions. Brown (1994) suggests three points related to the instruction given by the teacher. The first one is explaining the purpose of the activity. The teacher has to be able to explain it as it becomes the basic of aims' achievement in teaching and learning processes. The second one is explaining the procedures. The students should know what they are going to do; the stages that they have to do. According to Alexander (2000), the activity has to be started from the simple to the more complex one. For example, in doing writing task, the first procedure is writing the framework of the text before producing the paragraph. The last one is explaining the specific instructions, such as restatement of the purpose, rules the students to follow (ex: don't show your schedule to anyone else), establish a time frame (ex: you have ten minutes to complete the task), and assign roles to students (ex: you should be the time keeper).

The next point in implementing group work is offering verbal presentation about group work. As explained by Brooks (2010), the teacher should explain the group work verbally in order to guarantee that the students understand about the task given and how to do it. He states that it should take place in the first tutorial. In this case, the teacher is recommended to show the commitment in implementing group work and make sure that the students know why they learn by using group work in discussing the topic given. In other words, the students should also be given a chance to ask questions about any aspects of the lesson (Bloom and Gardner, 2002).

Additionally, the teacher also has a role as a controller. Brown (1994) states that a teacher should help students to determine what the students do and help them in deciding what language form they should use. The teacher is also suggested to controll and organize the class hour. It is supported by Alexander (2000) and Bloom and Gardner (2002) in which they state that the teacher has to set a target and deadline of colleting the task given. Because of that, the students can take handle in managing the time they have to finish the task.

Moreover, in managing the group work the teacher also has a role as a resourcer who can give advice and counsel when students seek it. Furthermore, the teacher may also give support for the learners. It means that presenting an option in a way that can encourage free choices and can show respect for the learners' decision (Nunan, 2003).

Briefly, it can be stated that the teacher takes important roles in implementing group work. The teacher has so many functions so that the group work can be run well. These functions are analyzing students' knowledge, giving explicit detail instructions, offering verbal presentations about group work, functions as a controller, facilitator, resourcer, and monitor. Because of that, the teacher has a significant contribution in implementing group work. 


\section{Method}

This study practically used a qualitative approach. The aim was to analyze how the English teachers plan and implement group work during teaching and learning processes. The study was conducted at MAN Kota Solok (High School). There are 5 English teachers in MAN Kota Solok High School. One English teacher taught at Grade X, two English teachers taught at Grade XI and two others taught at Grade XII. For this research, the subject chosen for the study were only 3 teachers because they were only teachers who implemented group work in the classroom.

The research was conducted by means of observation and interview. In collecting the data, all the English teachers were observed during implementing group work in the classroom. The observation was done several times till the data gotten were saturated. In this case, each of the teachers was observed 5 times. To get the data from observation, the researcher as an observer did not record the process in the classroom through video, but took a note. It was aimed to avoid any interference for the teacher and students. Note taking taken during observation was guided by points of teacher's role in planning and implementing group work. Besides, the data were also collected through interview. The English teachers were interviewed based on what they did during implementing group work in the classroom. It was used to triangulate the data gotten from observation. Thus, the data collected were valid. The interview was a kind of semi-structure interview. The data were analyzed scientifically by adapting the technique of data analysis proposed by Patton (1990). The steps in analyzing the data are explained as follow:

1. Epoche.

In this step, the researcher differentiated between participants' point of view, assumption or prejudice. In other word, the researcher should be able to clarify any personal bias from the data collected.

2. Phenomenological reduction

The researcher gathered the original data which related to the research. Irrelevant data should be put out. Moreover, the researcher got the real facts of the data.

3. In grouping the real data, the researcher followed the following steps:

a. Decided any phrases or statements that show the facts of the phenomenon.

b. Interpreted the meaning of the phrases or statements.

c. Explained the participants' opinion about the statements.

d. Looked over these meanings for what the essential opinion of the participants.

e. Offered a tentative statement, or definition, of the phenomenon in terms of the essential recurring features identified.

4. The textual portrayal of each theme The researcher described experience of the participants.

5. Development of structural synthesis

The researcher described the deeper meaning of participants' experiences; the true meaning contains in those experiences.

\section{Data Analysis and Discussions.}

The data of the research were

analyzed based on two main points; how the teachers planned and how they implemented the group work. The way the teachers plan the group work is indicated by 4 main points; selecting appropriate activity, deciding the goals, determining the size of the groups and 
deciding the members of the groups. Moreover, the indicators of implementing group work are arranging students' seat, giving explicit detailed instructions, discussing the progress of group work, controlling and providing any resources, and allocating time to test students' comprehension. All these roles are important to guarantee the group work activity can be run well. As stated by Chiriac (2011), in running the group work, the teacher does not only play as a teacher, but also as a leader. The following are the result of the research related to how the English teachers at MAN Kota Solok planned and implemented group work in their classroom.

Planning the group work. Planning the group work is a crucial stage in conducting group work. It involves the teachers to arrange the group work and to lead students to work in groups. The first stage in planning phase is selecting appropriate activity. Based on the observation, the teachers did not specify a specific form of group work, such as simulation, opinion exchange, etc. However, those teachers formed the students to work in groups in order to produce an expository text based on the topics given. An interesting point is that how the teachers used simple form of group work but it worked well since it was appropriate to the goals of teaching and learning processes.

It directly links to the second stage in planning in which the teachers explain the goals of teaching and learning processes for that meeting. Based on the observation, the teachers stated directly and even indirectly what the students should achieve at the end of the lesson. Shortly, the teachers informed the students about the goal of teaching and learning process, which was writing an expository text. All the teachers stated it orally at the beginning of the lesson.

Based on the description above, there is a correlation between the goal of learning and the activity chosen. The activity should be in line with the purpose of the learning activity. Since the activity is a medium to achieve the goals of learning, the teacher should consider how the students work to achieve the goal. It leads the teachers to choose the most appropriate type of group work. Shortly, it can be stated that the teachers have considered it well. It is relevant to the theory stated by Nation (1989) in which he proposes that the activity chosen for group work should be established and appropriated as well as the goal and aims of teaching and learning processes.

Moreover, the teachers also demand to determine the size and the members of group work. Since the teachers have a responsibility to control and manage the students, the teachers are also demanded to arrange the students on their own groups. Based on the observation, all the teachers decided the members of the group by considering the total numbers of students in one class. The teachers have grouped the students into small group in which one group only consisted of 4 or 5 students. In the other side, the teachers had two ways in determining the members of the groups; grouping the students by means of their level of ability (combine smart students and slow students) and by means of their seat. Two teachers decided the members of the groups based on their seat. The teacher argued that it was the simplest way to group the students. The following transcriptions shows the fact.

\section{Transcription 1:}

R: 'iko anak-anak dikelompokkan berdasarkan tampek duduaknyo se nak pak?' ('the students are grouped based on their seats, aren't they?')

T2: 'iyo' ('yes')

R: 'baa ndak digabuang se pak yang kemampuan bagus jo yang kurang di ciek kelompok?' ('Why don't you put one good student for each group?') 
T2: 'lamo kalau model turin. Heboh, ndak cukuik waktu beko.' ('It takes a long time and they will be noisy.')

R: 'lah ado bacubo tu pak?' ('Have you tried it?')

T2: 'alun lai. Apak model ko se taruih.' ('Not yet. I always do just like this.')

Based on the transcription above, the teacher confirmed the argumentation given by $\mathrm{R}$ (researcher) in which the researcher tells that the students were divided based on their seats. In other words, the teacher did not group the students based on their level of ability. In fact, this decision leaded to the failure of group work. The groups that do not have any qualified member cannot elaborate their writing well. In other words, they do not have anyone who can lead them to write a good writing. Thus, it can be academically argued that dividing the students based on the levels of ability is a crucial step to assure the successful of group work.

On the other hand, one teacher grouped the students based on their levels of ability. The teacher put at least one smart student for each group. The class had 7 groups and the teacher united students with high level of ability with the lower ones. The data of observation proved that the smart students tried to handle the task by themselves. This phenomenon surely was not expected since the aim to unite the students was to activate students' participation among the group members. The data of observation tell that it was influenced by how the teachers treated them during the process of implementing group work. In other words, the teacher's task was not fully fulfilled when she grouped the students. The teacher did not monitor how the students work in group. She only grouped the students and then focus on the final product. As stated by Burke (2011), group work may not give any advantages for students if some group members just rely too heavily to the other members. In this case, the teacher is the one who should guarantee that all members work together. It is in line with the idea proposed by Biehler (1997). He explains that the groups formed should be heterogeneity. It is also suggested containing different levels ability of students so that they can help each other. Thus, the group can work optimally. Besides, he points the important aspect in conducting group work; that is teacher's role. He said that the students can work together in their group if the teacher shows how to help each other in order to overcome problems and complete whatever task has been assigned on their group. To sum up, table 1 shows teachers' activities in planning phase of group work.

Table 1:

Teachers' Activities in Planning Group Work

\begin{tabular}{clcl}
\hline No & Stages in planning group work & Teacher's activity & Notes \\
\hline 1 & Selecting appropriate activity & $\sqrt{ }$ & $\begin{array}{l}\text { Simple and regular } \\
\text { type of group works }\end{array}$ \\
\hline 2 & $\begin{array}{l}\text { Explaining goals of teaching and } \\
\text { learning processess }\end{array}$ & $\sqrt{ }$ & Oral statement \\
\hline 3 & Deciding the size of the groups & $\sqrt{ }$ & $\begin{array}{l}\text { Based on total } \\
\text { numbers of students }\end{array}$ \\
\hline 4 & $\begin{array}{l}\text { Determining the members of the } \\
\text { groups }\end{array}$ & $\sqrt{ }$ & $\begin{array}{l}\text { Based on students' } \\
\text { seat and not their levt } \\
\text { of ability }\end{array}$ \\
\hline
\end{tabular}


In accordance with explanation above, it can be academically stated that teachers have a great responsibility to plan the group work by considering the goals of teaching and learning processes and linking it to the activity chosen. The teachers are also responsible to decide the members and the size of group work. All decisions influence the way the students work on their groups. In this case, the way the students work on their group does not only depend on how the planning arranged by the teachers, but it also requires the teachers to control and facilitate the students during the process of group work.

\section{a. Implementing group work}

The next phase in conducting group work is implementing group work to accomplish the task. The first stage in this phase is arranging students' seat. It is one of the significant steps taken by the teacher during implementing group work activity. In fact, the data of observation proved that 2 of 3 teachers arranged the students' seat in a good arrangement. The students were divided into groups and the teachers decided their seat so that the teachers could monitor the students' work. Besides, the teachers could also walk around the class and observed each group easily. In this case, it can be stated that the teachers realized the importance of arranging students' seat in order to observe students' progress and participation.

However, one of the teachers was not really aware about the importance of arranging students' seat. She allowed the students to arrange the group seats. Consequently, some groups chose to sit in the corner at the back so that the teacher could not optimally control students' work and participation. The teacher cannot walk around the groups since there was only a little space between groups to the other groups. As a result, the teacher only monitored the groups who sit at the front regularly. In fact, there were only 3 groups there. The other groups sat at the back, specifically at the back in the corner. An interesting point is the teacher did not realize what she did. She did not recognize that she did not monitor all the groups regularly. The worst one is she was not aware that it was caused by her decision related to students' seating arrangement. The reason behind this decision was lack of knowledge about the influence of seating arrangement. It was proved by the interview as transcript below:

\section{Transcription 2:}

$\mathbf{R}$ :'banyak yang mangecek kalau pengaturan tampek duduak ko mempengaruhi hasil karajo anak. Baa menurut ibukt $u$ ?'('Many education experts and practitioners argue that seating arrangement influence the way the students works. What do you think about it?')

T: "maksudnyo baa ko?" ("What do you mean?')

R: "yo baa wak ma atur tampek duduak anak ko ma agiah pengaruh $k$ hasil karajo nyo buk. Misalnyo bantuak patang ko kan ado yang bara kelompok tu nyoh, duduak agak kasuduik kiri belakang kelas tu. Lai ndak payah anak-anak tu atau ibuk dalam melakukan kerja kelompok dek nyo" ('the way we arrange students' seat give such influence to the result of their discussion, for example, just like when some students chose to sit at the back, in the corner. Don't you think it disturb the students or even you in controlling the groups?')

T: 'indak do nak.' ('I am not sure')

R: 'jadi ndak ado pengaruhnyo ka ibuk do? Maksud ni, lai ndak payah gai ibuk pai bajalan ka kalompok tu?' ('so, doesn't it influence you? I mean, don't you get any difficulty in walking around the groups?') 


\section{T: 'lai indak do' ('I don't think so')}

The transcription of interview above tells that the teacher did not consider seating arrangement. The teacher did not even know and realize how seating arrangement influenced her in controlling students' progress. In fact, it gave a significant influence on the way the teacher controlled and facilitated the students during group work activity. As explained by Nation (1989), the seating arrangement of the members of the groups is categorized important as it affects the way students communicate on the groups. The teacher should be able to decide whether the students need to talk face to face or not. It is supported by the finding of the research done by Aman (2005) in which he found that the students should work well when the teacher arranges the seating arrangement. It influences their focus in accomplishing the task given. Furthermore, Kasim (2015) also strengthens that lack of teacher's control in monitoring students' work in their group can be one of the disadvantages that should be solved.

Additionally, the second step in implementing group work is giving explicit detailed instruction. The detailed instruction includes explaining the purpose of activity, explaining the procedures, and explaining the rules. Based on the observation, all teachers explained the purpose of group work activity when the teachers informed that the goal of learning was to produce an expository text. The teachers informed that the students had to work in groups because it can help them to write the text easier. The teachers explained that they can elaborate the ideas together and try to produce an expository text together. It is one of important steps since it points up that the students have to realize why they should accomplish a task. It is supported by Brooks (2010) in which he states that the teacher should explain the group work verbally in order to assure that the students understand about the importance of task given and how to do it. He states that it should take place in the first tutorial. In this case, the teacher is recommended to show the commitment in implementing group work and make sure that the students know why they learn by means of group work. In this case, the students should also be given a chance to ask questions about any aspects of the lesson (Bloom and Gardner, 2002).

Moreover, explaining the procedures of group work is also the significant step done by the teacher. The data of observation proved that all the teachers explained the procedures of the task through verbal and/ or written form. One of the teachers wrote down the procedure on the whiteboard and explained it orally before the students joined to their groups. This activity was started before the students directly worked on their groups. The other teachers explained the procedures orally. However, the explanation of the procedures was only as general guidelines in which they explained what the students should do for accomplishing the task. It is not relevant to the theory stated by Brooks (2010) in which he states that the instruction given to the students should be clear in order to avoid misunderstanding in doing the task given. It can be academically argued that the teacher has to explain the procedures of group work in a detail way to avoid any mistake or even failure. Similarly, it is also supported by the research done by Yunfeng (2005) in which he states that the teacher should give clear instruction of the task so that the activity that is going to be done could be clear for students.

Explaining the rules of group work is the next step in implementing group work. It gives a concrete impact for any action taken by students. In fact, the data of observation tell that the teachers in the classroom did not 
give details information about the rules of group work and even any impact whenever the students break the rules. The teachers only informed the task which should be accomplished. Consequently, the students did not know that they have to follow such rules so that they made their own rules. It directly impacted to the progress and quality of the group work. As stated previously, some smart students tended to take control in accomplishing the task. The worst one is those students did not invite the other members to work together in accomplishing the task. In the other side, the other members of groups also did not take the responsibility or even wanted to know how to do the task. In other words, the students did not work together because some of them did not participate at all during the discussion. It is not in line with Brown's statement (1994) in which he states that the teachers could maintain that there is no chance for students to take time for any other activity. They have to focus to the task given because there would be a consequence of what they have done. It results a positive condition to finish the task as well as possible.

Allocating the time to discuss the result of group work activity is the next point in implementing group work. The data of observation tell that the teachers tried to communicate with the students to check the progress of students work. The teacher walked around the classroom and asked students' progress. However, the data of observation proved that none of the teachers asked whenever the students got difficulties during teaching and learning processes. The teachers walked around the classroom and monitored students' progress just for asking students' progress. In two moments observed, one of the teachers helped the students about the tense used because the student asked about it. However, the teachers did not ask the students about any problems during the process of accomplishing the task. In fact, the questions asked by the teachers dominantly related to "how far the progress of the group task is", and "whether the group have finished or not". It is supported by interview data as transcript as follow:

\section{Transcription 3:}

R: 'ni caliak patang ibuk bajalan kaliliang kelas. Itu mananyoan sampai dima anakanak ko siap yo buk?' ('Yesterday I saw you walked around the class when the students worked. Is it aimed to ask students' progress?')

T3: 'iyo. Wak kan harus bajalan juo sakalisakali kan bia anak-anak ko ndak bamain se. jadinyo tau awak tetap mamparatian.' ('yeah, sometimes we have to walk around to avoid any noise because they know we watch on them')

R: 'tu apo se kiro-krio komentar yang biaso ibuk agiah ka anak-anak ko?' ('may I know any comment you give for them?')

T3: 'yo ditanyokan, lah sampai dima, baa lai bakarajo sadonyo ko indak' ('I ask about how far the progress has been accomplished, whether they work or not.')

R: 'biasonyo ado keluhan dari anak-anak ko ndak buk?' ('did the students consult any problems?')

T3: 'ado juo, tapi jaranglah. Yo yang pokoknyo wak harus memonitor anakanak ko. Kok indaknyo bias sorang atau baduo se yang karajokan.' ('yeah in a few moments, but the point is we had to monitor the students. if we don't, there will be only 1 or 2 students who work.')

The transcription above proved that the teacher walked around the class was not for checking whether the students faced any difficulties in accomplishing their tasks or not. However, they tried to check students' 
progress and created a sense for the students that they were monitored. In fact, what the teacher did is not totally wrong. However, it should be in line with teacher's role in group work activity as a facilitator. As the facilitator, the teacher is demanded to help and facilitate the learners whenever they get problem, check their progress, correct any students' mistakes and errors during their group work activity. Shortly, teacher's responsibility is not limited only on checking students' progress but also helping and facilitating them in doing their task. By moving towards every group, the teacher could see the problems faced by students and reduce the noise level of students (Bloom and Gardner, 2002). The teachers moved towards the groups but they did not fully listen to students' discussion. They only made sure that the students did not do gossiping or made noise. It may affect to the successful of the group activity as this point contributes on controlling what students do.

Theoretically, discussing and checking students' work and facilitating their discussion are cores of discussion. It is supported by Bloom and Gardner (2002) in which they state that a discussion is one of the important phases in conducting group work as it provides a chance to discuss the result of what students have done. Related to this point, Aman (2005) found that a teacher should give opportunities for students to communicate and discuss what they have done. Academically, it can be stated that a teacher should always allocate time for students to discuss result of group work activity.

The last stage that was not applied by the teachers was allocating the time to test students' comprehension related to the topic discussed. Based on the data of observation, none of the teachers allocated time for evaluating students' comprehension related to the materials discussed. Based on the data of interview, one of the teachers stated that she assessed students' ability based on their participation during group work activity and their final results of the task. The transcript of the interview is stated as follow:

\section{Transcription 4:}

R: 'kan pas anak tampil ka muko patang, ndak sadonyo dalam kelompok yang ikuik mangecek do kan buk. Tu baa ibuk manilainyo tu buk?' ('When the students were asked to perform, not all the members reported. So, how do you assess their comprehension?')

T: yo baa yo, kan waktu nyo bakarajo dikelompk nyo tu ibuk caliak partisipasinyo. Jadi lebih $\mathrm{ka}$ partisipasinyo lah.' ('I evaluate their comprehension when they still worked on the group. I mean, it is mostly about their participation.')

R: 'jadi ndak masalah do buk kalau bantuak patang tu?' ('so, it means that the students are allowed to not perform in fornt of the class to report the result of their group discussion?')

T: 'yo wak lebih menekankan partispasi di kelompk lah. Pokoknyo berpartispasi.' ('I more focus on their participation on their group.')

R: 'tu pas nyo tampil patang tu, indak ado diagiah apo namonyo ko...feedback baliak do nak buk?' (Didn't you give any feedback when they performed?)

T: 'maksudnyo?' ('what do you mean?')

R: 'yo saran, perbaikan hasil karajonyo gitu.' ('any suggestion, correction for their works')

T: 'yo nilai nyo kan lah ado tu. Pokoknyo tugasnyo kan siap. Yo lah gitu se.' (oh I see, they have got the scores. The point is they accomplished the task. That's it.)

The transcripts of the interviews above tell that the teacher generally assessed students' ability based on two indicators; participation and the final result of the task. These two points represent process and product of learning. However, it cannot assure that the students understand the 
learning materials. Moreover, the others teachers argued that they did not have enough time to evaluate every single material in every meeting by doing a test. The data of observation show that the teacher spent much time for preparing the students on their groups and allocating the time to work on their group. The degree of students' ability in
English influenced their speed in accomplishing the task. In other words, the teachers did not have enough time to assessthe students individually.

All teachers' activities in implementing group work as previously explained is simplified as stated in table 2 .

Table 2:

Teachers' activity in Implementing Group Work

\begin{tabular}{clcc}
\hline No & Stages in Implementing Group work & $\begin{array}{c}\text { Teachers' } \\
\text { Activities }\end{array}$ & Notes \\
\hline 1 & Arranging students' seat & $\mathrm{X}$ & Only 2 teachers did it \\
\hline 2 & Explaining the purpose of activity & $\sqrt{ }$ & $\begin{array}{c}\text { Oral and written } \\
\text { explanations }\end{array}$ \\
\hline 3 & Explaining the procedures of group work & $\sqrt{ }$ & \\
\hline 4 & Explaining the rules of group work & $\mathrm{X}$ & $\mathrm{X}$ \\
\hline 5 & $\begin{array}{l}\text { Allocating time to discuss and check } \\
\text { students' works }\end{array}$ & $\begin{array}{l}\text { Allocating time to test students' } \\
\text { comprehension }\end{array}$ & $\mathrm{X}$ \\
\hline 6
\end{tabular}

In accordance with explanation above, it can be academically interpreted that it happened because there was no exact rules to be followed. As stated in the previous page, the teachers did not explain any detail rules and the consequence for any action taken. The students did not inform that all the members have to take a part in reporting the task. Consequently, they were not ready to perform in front of the class. It demanded the smart students to take handle in reporting the result of their work. As a result, the teacher cannot evaluate students' comprehension or ability related to the task given. It was the exact reason why the teacher only focused on the participation of the students. In other words, it can be academically stated that students' participation is important, but students' comprehension cannot be left behind since it is the main goal of teaching and learning processes. Thus, evaluating or testing students' comprehension is the most important stage in order to evaluate teaching and learning processes as a whole.

By considering the fact based on observation that the teacher cannot fully control and monitor students' work on their groups, it is reasonably argued to say that the teachers cannot optimally observe students' participation on their group. The seating arrangement that disturbs the teacher to monitor all the students and the total numbers of groups in the class decline the capacity of the teacher to observe and notice every student's progress and participation. Shortly, the teacher needs to allocate the time for assessing students' comprehension related to learning materials that they discussed on their groups. It is supported by Bloom and Gardner (2002) in which they explain that allocating time for group assessment or test allows and motivates students to practice working in groups. They are indirectly pushed to work seriously and try to 
understand the materials as they know that there would be such kind of small test related to the topic discussed.

Accordingly, all stages in implementing group work as previously explained require the teacher to help students to be more active by means of giving advices, motivating, facilitating, and controlling group dynamics. In other words, a teacher takes a role as an advisor and a motivator who can give advice and counsel to the students (Nunan, 2003). However, teacher's task does not completely work if only helping the students when they ask. When some students are too afraid for asking questions, the teachers are demanded to be more active to observe and help students who get difficulties. In addition, monitoring students by means of walking around the class is not only to monitor students' progress but also to motivate the students, give correction, and help them as well. As the teacher is responsible to control the achievement of the goals, the teacher should correct the points that made by the students (Bloom and Gardner, 2002). It is supported by Bloom and Gardner (2002) in which they state that listen to general group discussion is important as the teacher can gain a picture of which groups are operating successfully and which one is struggling.

\section{Conclusion and Suggestions}

Teachers have a great role in assuring the success of group work activity. Conducting group work needs a high consideration related to plan and implement the group work. The teachers have to decide every single step by looking at the goals of conducting group work and the goals of teaching and learning processes. Whenever the teachers have planned the group work well, they still have to control the students during the implementation of group work. Shortly, it can be stated that good planning can lead to a good implementation, but it is not a warranty that good planning will always have good implementation. Although planning is an important stage in group work, controlling and monitoring students and any relevant improvisation during the process of implementation of group work have to be done by the teachers. Additionally, it can be

stated that in terms of learner-centered instruction, the teachers still have great contributions and roles in planning and implementing the group work. In other words, the students cannot work alone without any guidelines and rules.

Based on the discussion presented above, the teachers are suggested to apply all principles of conducting group work activity. As the teachers have great contribution of the successful of group work activity, it is expected that the teacher can stimulate students to be more active so that the goals and aims of teaching and learning process can be achieved. However, the teachers should also evaluate the process of group work in order to evaluate whether the activity has worked well to achieve the goal of teaching and learning processes.

\section{(C) Absharini Kardena}

Absharini Kardena was born in Solok, West Sumatera, Indonesia, 19 March 1988. She studied English education for her Bachelor Degree at Universitas Negeri Padang in 2006-2011 and then continued her study for Master program of English Education Program at Universitas Negeri Padang in 2011-2013. She taught at the English Education Department of Bung 
HattaUniversity from 2013 to 2016, before she became an English lecturer at English Education Study Program of Institut Agama Islam Negeri (IAIN) Bukittinggi up to the present.

\section{References}

Alexander, M. (2000). 'How to Plan and Organize the Work of a Team'. Retrieved on 31 August 2010 from www.howtodothings.com.

Aman, D. (2005). The Effect of Small Group work Discussion and Language Learning Strategies on English Speaking Class at SMAN 1 Nan Sabaris Padang Pariaman (2005). (Unpublished Thesis). Padang: Universitas Negeri Padang.

Biehler, S. (1997). Psychology Applied to Teaching'. Houghton Mifflin Company. Retrieved on 19 August 2010 from http://college.cengage.com/education/p bl/tc/coop.htm.

Black, K. (2008). Giving and Receiving Feedback. Retrieved on 31 August 2010 from www.learning.ox.ac.uk/rsv.php? $=319$.

Bloom, B \& Gardner, H. (2002). Group work. Retrieved on 31 August 2010 from www.edsw.usyd.edu.au.

Brooks, A. (2010). The Best Way for Teachers to Organize Group work. Retrieved on 31 August 2010 from www.psy.gla.ac.uk/ steve/feedback.ht $\underline{\mathrm{ml}}$.

Brown, H.D. (1994). Teaching by Principles: An Interactive Approach to Language Pedagogy. New Jersey: Prentice Hall Regents.

Burke, A. (2011). Group work: how to use group work effectively. The Journal of Effective Teaching. 11(2): 87-95.

Chiriac, E. (2011). Management of Group Work as A Classroom Activity. World Journal of Education. 1 (2): 1-14. doi:10.5430/wje.v1n2p3.

Cohen, E. (1994). Designing Group work: Strategies for the Heterogeneous
Classroom. Retrieved on 28 December 2009 from

www.julieboyd.com.au/ILF/pages/mem bers/designgrpwork.pdf.

Cookes, G \& Chaudron,C. (1991). Teaching english as a second language or foreign language. (pp:49-58). In Celce Murcia (ed). Guidelines for Classroom Language Teaching: second edition. New York: Newbury House.

Creswell, J. W. (1998). Qualitative inquiry and research design: Choosing among five traditions. Thousand Oaks, CA: Sage Davis, Barbara. 2009. Classroom organization. Retrieved on 31 August 2010 from www.brighthub.com/education/k12/articles/21256.aspx.

Deckert, G. (2004). The communicative approach: addressing frequent failure. Retrieved on 28 December 2009 fromwww.englishjournal.com.

Evertson, CM. (1984). Classroom Management for Elementary Teachers. New Jersey: Prentice Hall, Inc.

Harmin, M. (1994). Inspiring Active Learning: a Handbook for Teachers. Virginia: Association for Supervision and Curriculum Development.

Hayden, K. (2010). Tips for Organizing Groups for Group work. Retrieved on 31 August 2010 from www.ehow.com.

Kasim, U. (2015). Implementation of Group Work in the Classroom. Lingua. 12 (1): 97-106.

Kizlik, R. (2010). 'Classroom management, management of student conduct, effective praise guidelines, and a few things to know about esol thrown in for good measure'. (Online). Retrieved on 1 
July 2010 from

http://www.adprima.com/managing.htm

Laoli. A. (2008). The effect of interactive strategies on the student's English reading comprehension at SMA Negeri 2 Gunung Sitoli. (Unpublished Thesis). Padang: Universitas Negeri Padang.

McDonough, J. (1993). Materials and Method in ELT. Massachusetts: Blackwell Publisher.

Nation. (1989). Group work.Retrieved on 28 December $\quad 2009$ from www.victoria.pdf.com.

Nunan, D. (2003). Practical English Language Teaching. Boston: McGrawhill.
.—. (1998). Language Teaching Methodology. Longman: Edinburgh.

Nurtita. (2007). 'Improving students' motivation and speaking skill through small group'. (Unpublished Thesis). Padang: Universitas Negeri Padang.

Patton, Q. (1990). Qualitative Evaluation and Research Methods. $2^{\text {nd }}$ ed. London: Sage Publication ltd.

Smith, M.K. (2008). What is group work. Retrieved on 3 February 2010 from www.infed.org/groupwork/.

Yunfeng, Z. (2005). Task type and teacher's role: two important factors in effective group learning. Retrieved on 3 February 2010 from www.ct-net.net/tc-sample6-3. 